IZA DP No. 8629

Public Housing Magnets: Public Housing Supply and Immigrants' Location Choices

Gregory Verdugo

November 2014 


\title{
Public Housing Magnets: Public Housing Supply and Immigrants' Location Choices
}

\author{
Gregory Verdugo \\ Banque de France \\ and IZA
}

\section{Discussion Paper No. 8629 \\ November 2014}

\author{
IZA \\ P.O. Box 7240 \\ 53072 Bonn \\ Germany \\ Phone: +49-228-3894-0 \\ Fax: +49-228-3894-180 \\ E-mail: iza@iza.org
}

\begin{abstract}
Any opinions expressed here are those of the author(s) and not those of IZA. Research published in this series may include views on policy, but the institute itself takes no institutional policy positions. The IZA research network is committed to the IZA Guiding Principles of Research Integrity.

The Institute for the Study of Labor (IZA) in Bonn is a local and virtual international research center and a place of communication between science, politics and business. IZA is an independent nonprofit organization supported by Deutsche Post Foundation. The center is associated with the University of Bonn and offers a stimulating research environment through its international network, workshops and conferences, data service, project support, research visits and doctoral program. IZA engages in (i) original and internationally competitive research in all fields of labor economics, (ii) development of policy concepts, and (iii) dissemination of research results and concepts to the interested public.
\end{abstract}

IZA Discussion Papers often represent preliminary work and are circulated to encourage discussion. Citation of such a paper should account for its provisional character. A revised version may be available directly from the author. 


\section{ABSTRACT \\ Public Housing Magnets: Public Housing Supply and Immigrants' Location Choices ${ }^{*}$}

This paper investigates how a reform allowing immigrants with children in France access to public housing during the 1970s influenced their initial location choices across local labour markets. We find that cities with higher public housing supplies have a large 'magnetic effect' on the location choice. The estimated effect is substantial and quantitatively similar to the effect of the size of the ethnic group in the urban area. In cities with higher public housing supply, these immigrants tend to benefit from better housing conditions, but non-European immigrants are also more likely to be unemployed.

JEL Classification: J15, R50

Keywords: public housing, social housing, immigration, location choice

Corresponding author:

Gregory Verdugo

Banque de France

31 rue Croix-des-petits-champs

75049 Paris Cedex 01

France

E-mail: gregory.verdugo@banque-france.fr

\footnotetext{
* Forthcoming in Journal of Economic Geography. Data used in this paper - except data from 1999 Census - are available upon request for researchers from the Centre Maurice Halbwachs. The author accessed the 1999 Census data via the Centre d'Accès Sécurisé Distant (CASD), dedicated to the use of authorized researchers, following the approval of the Comité français du secret statistique. This research was partially supported by a French State grant ANR-10-EQPX-17 (Centre d'accès sécurisé aux données - CASD). I thank three anonymous referees, Karin Edmark, Thierry Magnac, Eric Maurin, Javier Ortega, Amine Ouazad, Jean-Louis Pan Ké Shon, Gilles Saint-Paul, Karine Van Der Straeten, Etienne Wasmer, and seminar participants in many places for insightful comments. This paper does not necessarily reflect the views of the Banque de France.
} 


\section{Introduction}

The economic outcomes of immigrants in their host countries depend in large part on their location. New immigrants are more likely to succeed economically if they are located in cities with a higher labour demand. For these reasons, extensive research has been conducted on whether the settlement patterns of new immigrants respond to differences in local economic conditions. ${ }^{1}$ The evidence from the literature is mixed and suggests that other factors, such as the availability of local ethnic networks, have a larger influence on immigrants' location decisions.

Recently, a growing stream of literature has investigated whether differences in welfare availability also influence the location of immigrants. It has been noted by Borjas (1999) and others that unlike natives, recent immigrants might be disproportionately attracted to places with more generous welfare policies because initially, they do not have any local ties to a particular region. ${ }^{2}$ Localised differences in welfare benefits might attract large numbers of immigrants to relatively generous regions, and these inflows might be more difficult to absorb by the local labour market.

In this paper, we examine the impact on the location choice of a welfare program that is quite important for immigrants: public housing. Public housing is currently a major policy issue in many countries, particularly in Europe. In 1996, public housing accounted for more than $40 \%$ of the total housing stock in the Netherlands; $20 \%$ in Austria, the United Kingdom, Sweden, and Denmark; and more than $10 \%$ in Germany, Ireland, France, and Belgium (Priemus and Dieleman, 2002).

\footnotetext{
${ }^{1}$ See, for example, Jaeger (2001,2008), Borjas (2001), Bauer et al. (2005), and Bartel (1989) for the U.S., Pischke and Velling (1997) for Germany, Desplanques and Tabard (1991), and Jayet and Ukrayinchuk (2007) for France.

${ }^{2}$ For the U.S., Borjas (1999) finds evidence of interactions between welfare and the location choices of immigrants, while Kaushal (2005) reports no impact. Giorgi and Pellizzari (2009) report a positive effect of differences in welfare benefits across European states.
} 
In most of these countries, immigrants are disproportionately represented in public housing. In Amsterdam, more than $80 \%$ of Turkish and Moroccan immigrants lived in public housing in 1990 (Musterd and Deurloo, 1997), and in London, 40\% of foreign-born residents were social tenants (Rutter and Latorre, 2008). In France, these rates are particularly high among non-European immigrants; $50 \%$ of immigrants from Algeria and Morocco lived in public housing in 1999 (Verdugo, 2011b).

These figures suggest that public housing policies are an important issue for immigration policymakers. However, there has been relatively little systematic research to date on the consequences of public housing policies for immigrant outcomes. ${ }^{3}$ In light of the recent welfare magnet literature, an important question is whether public housing influences the spatial distribution of immigrants across local labour markets, leading them to live in regions with better access to public housing but potentially less favourable labour market prospects.

This risk is not negligible because, in practice, spatial variations in the public housing supply across localities may be quite dramatic: in 1999, in France, public housing rates ranged from $13 \%$ of households in the urban area of Nice to $40 \%$ in Rouen. If public housing influences location choices, cities with large stocks might receive a disproportionate share of immigrants. Such a spatial mismatch might explain in part the high unemployment rates of low-skilled immigrants observed in some European countries, notably in France. ${ }^{4}$

However, empirically identifying the effect of differences in the public housing supply on immigrants' location choices and outcomes is difficult because cities might differ

\footnotetext{
${ }^{3}$ Previous important papers on public housing focused mainly on the U.S., where the supply of public housing is very low and declining, with a share of only $3 \%$ of occupied rental units in 2000 (Baum-Snow and Marion, 2009). Many papers focused on the consequences of living in public housing: see e.g., Jacob (2004), Currie and Yelowitz (2000).

${ }^{4}$ In France, the unemployment rate of immigrants from Maghreb or Africa was 16 points higher than that of natives in 2005 (Verdugo, 2009).
} 
systematically in unobserved ways that affect the location decision and are correlated with the availability of public housing.

To overcome these difficulties, we exploit a policy change in France that allowed the access to public housing to new immigrants with children during the 1970s, while this group was completely excluded during the 1960s. In addition, we use immigrants without children that are much less likely to be eligible to public housing as a comparison group. We identify the impact of public housing using a difference-in-differences approach, where we compare changes in the location choice of new immigrants with children with respect to immigrants without children before and after the implementation of the new policy. Under the hypothesis that the two groups would have reacted similarly to other unobserved factors influencing the location choice, a comparison of the changes in the location choices before and after the policy can identify the causal effect of public housing on the location choices.

We find that a one-standard-deviation increase (approximately 9\%) in the number of public housing units per household in the urban area increases the probability of choosing an urban area with 'average' characteristics by approximately $40 \%$. As the probability of choosing the average urban area is $3 \%$ in our sample, the model thus predicts that increasing the public housing supply per household by 9 p.p. will increase the probability of choosing such an urban area to $4.2 \%$. This effect is substantial, as it is quantitatively similar to the estimated effect of the size of the ethnic group living in the urban area.

These results are consistent with additional evidence we provide that new immigrants are less likely to live in overcrowded housing in cities with a larger supply of public housing. On the other hand, we also find that non-European new immigrants are more likely to be unemployed in these cities. Taken together, these results provide new evidence that public housing might negatively affect the labour market prospects of immigrants while having a positive impact on their housing conditions. 
These results provide an important contribution to the debates on how best to provide housing assistance for low-income families. One important implication of our results is that public housing policies might have important disadvantages relative to programs such as person-based vouchers, which can be more easily adjusted. In particular, our results suggest that persistent spatial differences in the public housing supply might influence the composition of cities by attracting low-skill immigrants, which may be detrimental for the labour market outcomes of these individuals.

These results notwithstanding, two caveats are in order. First, we do not investigate the factors underlying the negative correlation observed between employment outcomes and location in a city with a larger public housing supply. This negative correlation could reflect alternative mechanisms such as spatial mismatch, neighbourhood effects or the negative selection of individuals attracted by public housing. Further research is needed to disentangle the respective importance of each factor. Second, by focusing on the period just before and after a policy change, we mainly capture the direct effect of public housing on the location choice. However, as public housing increases the share of immigrants in some locations, it will also have an indirect effect through the creation of new ethnic networks. The direct effect of public housing that we estimate is thus a lower bound of its total impact on immigrant location.

The remainder of this paper is organised as follows. Section I discusses the theoretical framework. Section II discusses the data that we use, and Section III provides relevant institutional details about public housing and immigration in France. Section IV presents the empirical model. Section V discusses the main estimation results. Section VI provides evidence on the effect of public housing on housing conditions. The final section provides conclusions. 


\section{How Public Housing May Affect the Location Choices of}

\section{Immigrants?}

Consider a simple spatial equilibrium model (see e.g. Moretti, 2011). Unlike the baseline model in which all workers are identical, assume that individuals differ only with respect to their family size: there are households with and without children. Two types of housing are available in each city: private and public housing. Private housing is accessible to all households, but public housing can only be used by households with children, and housing costs are always lower in public housing. Individuals with large households will prefer to live in public housing if sufficiently low rents compensate for the differences in utility related to housing consumption in the public and private housing sectors.

Following Borjas (2001), now assume there are fixed costs of moving. Fixed costs may be explained by the existence of family or other social ties, for example, which might deter natives' internal migration, as emphasised by Borjas (2001). For sufficiently large fixed costs, differences in the public housing supply will not influence the location choice of natives. In contrast, newly arrived immigrants have already paid the fixed costs of migration. This implies that they should be more responsive to differences in welfare benefits across localities, as argued by Borjas (1999). ${ }^{5}$

These theoretical implications can be generalised to any welfare program with localised variations in benefits. However, two key aspects of public housing can be underlined. First, the benefits associated with living in public housing are relatively large. In France, rents for public housing were $40 \%$ lower on average than those in the private sector during the 2000 s

\footnotetext{
5 Bouvard et al. (2009) argue that public housing might also attract immigrants, particularly non-Europeans, because of the existence of discrimination in the private sector housing market. Immigrants will also prefer public housing if they have to bear higher housing costs in the private market than do natives because of discrimination. Algan et al. (2011) provide evidence that immigrants are not discriminated against in public housing and that the allocation of families follows a strictly delimited administrative process.
} 
(Trevien, 2013) and the 1990s (Le Blanc et al., 1999) and 30\% lower during the 1970s (Durif and Marchand, 1975). Thus, public housing offers a very good test for the welfare-magnet hypothesis by introducing potentially more spatial variation in the benefits of settling in different areas than other welfare programs.

Second, given that public housing constructions are durable, the spatial differences in the supply across cities will be costly to adjust over time. Differences in supply might persist over a long period of time and trigger persistent changes in the composition of the population if public housing attracts households with specific characteristics, such as immigrant households.

\section{The Data}

A key feature of the French case is the availability of high-quality data on public housing and immigrants over a relatively long time period. Our main analysis draws on the French Census of Population and Housing for the years 1962, 1968, 1975, and 1982, which we supplement with data from 1990 and 1999. The sampling rate is extremely high: 5\% for the 1962 Census; $20 \%$ for the 1975 Census; and 25\% for the 1968, 1982, 1990, and 1999 Censuses. Such high sampling rates ensure that we can study the location choices of relatively narrow subpopulations of immigrants separately without facing large sampling errors (Aydemir and Borjas, 2011).

As in the rest of the literature, the focus of our study is the initial location choice of male 'new immigrants', who are defined as immigrants who declared that they were living abroad at the time of the previous census. ${ }^{6}$ We focus on males because most female migration during the sample period was family-based. A new immigrant is defined as being in a household with children if he lives with at least one child.

\footnotetext{
${ }^{6}$ Unlike U.S. Census data, there was no variable indicating the arrival year for each foreignborn individual until the 1999 Census.
} 
Panel A of Table 1 presents the main characteristics of immigrant inflows to France from 1962 to 1999. Annual immigrant inflows during the 1990s were lower than those during the period before 1975, but they remained large nonetheless. Panel B describes the characteristics of male new immigrants with and without children for those who arrived in 1962-1968 and 1975-1982. New immigrants with children tended to be older and more educated. For all groups, the education level of new immigrants increased during the 1970s.

To approximate local labour markets, we use the 57 largest urban areas with more than 100,000 inhabitants in 1982. These urban areas were chosen by more than $86 \%$ of new immigrants in 1968 and 1982. Column 4 of Table 2 shows the spatial distribution of new immigrants in France across the largest urban areas. As in many countries, immigrants tend to be spatially concentrated: cities such as Paris, Lyon and Marseille receive much larger flows of immigrants than do other cities.

In the French context, public housing refers to rented housing units managed by local public housing authorities. One data constraint is that the 1968 and 1975 censuses did not collect information on public housing. For those years, we approximate the number of public housing units per urban area using the indicated construction year of each building from the 1982 census on dwellings. ${ }^{7}$

While public housing availability depends on both supply and demand factors, the existing evidence suggests that the number of public housing units per household might offer a reasonable proxy. Data from the 1996 and the 2002 Housing Condition surveys indicates that the average waiting period is, with few exceptions, proportional to the number of public housing units per household at the regional level. ${ }^{8}$ Figure 1 shows a clear negative relationship

\footnotetext{
${ }^{7}$ Because there were basically no demolitions of public housing units from 1968 to 1982, this method provides a relatively accurate approximation for those years.

${ }^{8}$ The average waiting period for new inhabitants in public housing is not collected in the Census. Waiting times are not available on earlier Housing Condition surveys. The small
} 
between the log average waiting times and the log of public housing per household across regions. However, the region Ile-de-France (in which Paris is located) stands out as an obvious outlier.

\section{Institutional Background of Public Housing}

To address an acute housing crisis, the first massive construction plan for public housing was launched in 1958. ${ }^{9}$ Panel $\mathrm{C}$ of Table 1 indicates that more than half of the existing public housing stock in 1999 was constructed between 1945 and 1975. Construction rates declined thereafter, but they remained relatively large, increasing the share of public housing per household from $25 \%$ in 1975 to $30 \%$ in $1999 .{ }^{10}$

Public housing construction projects were undertaken through cooperation between the central government and local authorities (mainly municipalities) through local public housing agencies. ${ }^{11}$ Politically independent municipalities could, in practice, veto any construction project. As a result of this decentralised organisation, large spatial disparities in the public housing supply arose across urban areas in France, as documented in Table 2. For example, the urban area of Antibes had a very low supply in 1990, with $10 \%$ of public housing units per household, while the urban area with the largest supply in 1990 was Rouen, with $41 \%$.

sample size does not allow for the estimation of specific waiting times for immigrants. See Appendix for details.

${ }_{9}^{9}$ War damage created severe housing shortages. A system of rent control implemented in 1948 drastically reduced new constructions despite very high demand.

${ }^{10}$ Over the sample period, public housing constructions have been highly durable: through 1999, there has been essentially no demolition of public housing units; in addition, there have been no policies converting public housing apartments into condominiums as there have been in the U.S. (see Stébé, 2007).

${ }^{11}$ There exist approximately 820 different public housing agencies in France. The boards of these organisations are composed of local politicians from different levels of the French local and national administrations. 
These spatial disparities can be explained by several factors. First, part of the dispersion of the initial stock of public housing is related to variations in war destruction. As described by Voldman (1997), the government used public housing to accelerate the pace of reconstruction in bombed cities. Second, according to evidence from Verdugo (2011a), a large share of public housing was constructed in places with higher housing demand during the 1960s. Given that public housing is durable, population changes and differences in the initial public housing stock explain a large share of the variation in the public housing supply over the period. ${ }^{12}$

An important factor is that the initial public housing stock is not related to immigration. In practice, initial construction was larger in urban areas with fewer immigrants: Figure $2 \mathrm{a}$ shows that there is a negative correlation between the immigrant share of the population and the stock of public housing in 1968. Figure $2 \mathrm{~b}$ shows this negative correlation appears to be spurious and disappears once controls for differences in bombing intensity are included. The fact that the initial stock is not related to immigration rules out a direct relationship between the settlement patterns of immigrants and the public housing stock.

\section{Public Housing and Immigration}

Eligibility rules for public housing are set by the central government and are thus uniform across France. Eligible families can apply in any municipality, regardless of their current location or nationality. Currently, the only requirements are to be legally living in France (as a French citizen or migrant with a valid residence permit) and to be living under a certain threshold of income per unit of consumption, which is set at a rather high level. ${ }^{13}$

\footnotetext{
${ }^{12}$ Left-wing politicians have also usually been more in favour of public housing in the recent period. However, the effect of differences in political partisanship on the evolution of the supply at the urban area level appeared to be negligible before the 1990s: see Verdugo (2011a).

${ }^{13}$ Currently, the number of eligible families is three times as large as the available supply of public housing, and the average waiting period varies widely at the local
} 
However, the accessibility of public housing to immigrants changed drastically between the 1960s and the mid-1970s. During the 1960s, the government wanted to discourage the family-based migration of immigrants from Maghreb and to provide incentives for return migration during periods of economic downturn (Weil, 2005). As a result, strict rules limited the eligibility of immigrants; crucially, public housing agencies required immigrants to first maintain residency for 10 years before applying (Schor, 1996, p. 214), which rules out an effect of public housing on immigrants who arrived during the $1960 \mathrm{~s} .{ }^{14}$ These discriminatory policies, combined with large immigrant inflows during the 1960s, resulted in many immigrants living in slums near French cities (Lequin, 2006).

In response to the increasing pressure from the public to eliminate immigrant slums, housing policy changed drastically throughout the 1970s, particularly after a new government was elected in 1974 and decided to end immigrant discrimination with regard to the access to public housing (Schor, 1996). As a result, non-European immigrants settled disproportionately in public housing in the subsequent decades. Table 3 shows that the share of immigrants participating in public housing increased by $10-15$ percentage points for immigrants from Africa and Maghreb from 1982 to 1990. Another remarkable feature is that in 1999, approximately half of the immigrants from Maghreb lived in public housing in 1999, a difference of 34 p.p. compared to natives. In contrast, neither the share of natives nor the share of European immigrants living in public housing changed substantially over the period.

A final important feature is that the participation rate in public housing varies widely with respect to family status because most public housing units are large dwellings specifically designed for families. Panel B of Table 3 shows that the participation rates of

level. In the extreme case of the Paris area, average waiting times are currently longer than five years (Guillouet and Pauquet, 2011).

${ }^{14}$ The participation rate of immigrants in public housing was much lower than that of natives during the 1960s: Pinçon (1976) reports that in 1968, only 5.5\% of foreign workers in the urban area of Paris lived in public housing, compared to $15.3 \%$ of natives. 
households without children or with only one person are quite low. This low participation rate reflects in a large part that some of them cohabit with other larger households in the same public housing dwelling.

\section{Empirical Methods}

With this background, we turn to a discussion of our econometric methods for estimating the impact of public housing on the location choices of newly arrived immigrants. The main challenge in estimating the impact of public housing is that differences in supply across cities might be correlated with the unobserved characteristics of the urban area that also influence location choices. In particular, public housing projects might be constructed as a response to immigrant inflows that were driven by other factors.

To address this issue, we exploit the above-mentioned fact that public housing authorities during the 1960 s required immigrants to have at least 10 years of residency in France and that this condition was relaxed during the mid-1970s. Our strategy is to compare the location patterns of new immigrants that arrived between 1962-1968 (observed in the 1968 Census), who should not have reacted to public housing, with those who arrived between 1975-1982 (observed in the 1982 Census) and potentially had full access to public housing. ${ }^{15}$ Using changes over time, we non-parametrically control for the effect of unobservable or omitted urban area characteristics that are constant over time, such as average temperature and other various amenities.

However, a key concern is the existence of trends that are correlated both with public housing supply and the location choice. Following Cascio and Lewis (2011), we use male new immigrants in households without children as a comparison group. This group should react similarly to changes in other unobserved factors but not to public housing because they are much less likely to be eligible. By differencing between groups, we eliminate the potential

\footnotetext{
${ }^{15}$ We do not use the arrival period 1968-1975 because it was a transition period during which the access to public housing was only partial for immigrants (see Weil (2005) p. 52).
} 
bias from the correlation between public housing and time-varying unobserved factors at the urban area level that influence the location choice. ${ }^{16}$

We use a discrete choice model where the dependent variable is one of the 57 urban areas included in our sample. To facilitate the computation of the standard errors and inference, as we are interested in a variable that only varies at the very aggregated urban area level, we follow the two-step method of Berry et al. (1995), which has been used recently to analyse location choices in Bayer et al. (2007) and Bayer and McMillan (2012). ${ }^{17}$

In the first step, assuming an additive stochastic utility function, we estimate the following conditional logit model separately for each group, denoted $g$, of male new immigrants with and without children who arrived in France in 1962-1968 or in 1975-1982:

$$
U_{i l k t}^{g}=Z_{l k, t-1} \theta_{t}^{g}+\gamma_{k t}^{g}+e_{i l k t}
$$

where $U_{i l k t}$ denotes the level of utility for a new immigrant $i$ from ethnic group $l$ provided by location $k$ that arrived between (Census) year $t-1$ and $t$ was observed in France in year $t$. The unobserved component of utility $e_{i l k t}$ captures unobserved factors affecting utility.

The set of control variables $Z_{l k, t-1}$ accounts for characteristics specific to each ethnic group in the location and includes the percentage of individuals from the observed ethnic group in the urban area population, their average number of years of education and the share of immigrants from the group who were married. We normalise all predictors in $Z_{l k, t-1}$ to have

\footnotetext{
${ }^{16}$ Some members of the comparison group might react to differences in supply if they live with households eligible to public housing. If this effect is non negligible, our estimates yield lower bounds. However, as discussed below, we do not find evidence that members of the comparison group were influenced by public housing.

${ }^{17}$ The model is simplified here with respect to Berry et al. (1995) or Bayer et al. (2007) because there are no random coefficients in the first step. The two-step method produces conservative estimates of the standard error because the number of observations corresponds to the number of locations in the choice set (Donald and Lang, 2007), which corresponds here to the level of variation of our variable of interest. In addition, using a linear model facilitates the treatment of endogeneity because standard 2SLS methods can be used.
} 
means of zero and standard deviations of one across the choice set of each individual ${ }^{18}$ Note that this model cannot directly include individual socio-demographic variables such as education level because they do not vary across cities (see e.g., Train 2003, p. 25). ${ }^{19}$

The parameters $\gamma_{k t}^{g}$ are specific urban-area-by-census-year fixed effects for each group. These parameters capture the 'adjusted' probability of choosing a given urban area after the effect of $Z_{l k, t-1}$ has been taken into account. The logistic form of the model and the standardisation of $Z_{l k, t-1}$ imply that each parameter can be directly interpreted as the percentage increase in the probability of choosing the reference urban area when the variable of interest increases by one standard deviation..$^{20}$

In the second step, we use this adjusted probability as a dependent variable. ${ }^{21}$ Using arrivals during 1962-1968 and 1975-1982, we first estimate separately for each group $g$ :

$$
\hat{\gamma}_{k t}^{g}=\delta_{g} p_{k, 75} e_{82}+\beta_{g} p_{k, t-1}+\Gamma_{g k}+X_{k, t-1} \alpha_{g}+u_{k g t}
$$

where the term $e_{82}$ is an indicator function equal to one if the immigrants are observed in the 1982 Census and zero otherwise. We estimate this model separately for male new immigrants with and without children. Our main coefficient of interest is $\delta_{g}$, which captures the effect of lagged public housing per household $p_{k, 75}$ on the utility of immigrants arrived after 1975. To

${ }_{18}$ This implies we use the relative dispersion of these variables within ethnic group and year averages rather than using the absolute value. For example, the average share in the population across urban areas is $1 \%$ for immigrants from Algeria and $0.01 \%$ for immigrants from Cameroon. Normalising allows the effect of a one standard deviation increase in the share of immigrants in both groups to be similar.

${ }^{19}$ In a discrete choice model, individual attributes can only be included if they are specified in ways that create differences in utility across the choice set, such as by using interactions. We experiment with more flexible models below.

${ }^{20}$ More precisely, the parameter $\gamma_{k t}^{g}$ can be interpreted as the log ratio of the probability of choosing urban area $k$ in period $t$ for group $g$ with respect to the urban area. See the Appendix for details.

${ }^{21}$ The estimates of this second-stage regression are consistent because the sample size used in the first- stage regression is always greater than the square of the number of alternatives (Berry et al. 2004 ). 
rule out the possibility that the potential correlation between public housing and location decisions comes from new housing that was built in response to immigrant flows, we use the lagged stock of public housing as evaluated from the previous census.

The public housing magnet hypothesis is true if $\delta_{g}$ is positive and significantly different from zero. We expect to find a significant effect of public housing on the location of male new immigrants with children but no effect or a small effect on those without children. Estimates of the parameter $\beta_{g}$ provide a test of our identification strategy: we should find that new immigrants do not react to differences in public housing before the reform if our empirical strategy is valid.

The model also includes a full set of lagged urban area-specific covariates $X_{k, t-1}$ that control for the effect of local labour market conditions on the two groups: we include the local unemployment rate, regional differences in wages and housing costs, and the share of the labour force employed in the manufacturing sector. As a proxy for the socio-demographic characteristics of the urban area, we include the share of immigrants in the population, the share of university graduates and the log of the total population.

As discussed previously, these simple estimates might be biased if public housing is correlated with time varying unobserved characteristics of the city. Under the hypothesis that immigrants without children do not react directly to public housing supply but react in a similar manner to unobserved factors correlated with public housing, we can use a differencein-differences analysis to get rid of these biases. We use the following differenced model:

$$
\hat{\gamma}_{k t}^{c}-\hat{\gamma}_{k t}^{s}=\tilde{\delta} p_{k, 75} e_{82}+\tilde{\beta} p_{k, t-1}+\tilde{\Gamma}_{k}+X_{k, t-1} \tilde{\alpha}+u_{k t}
$$

where the dependent variable $\hat{\gamma}_{k t}^{c}-\hat{\gamma}_{k t}^{s}$ captures differences in the probability of choosing the urban area $k$ for immigrants who are married with children relative to the comparison group 
of immigrants without children. ${ }^{22}$ By definition, the effect of any unobserved urban area characteristics common to both groups is differenced out, while urban area-fixed effects $\tilde{\Gamma}_{k}$ controls for the differential effect of these characteristics. Similarly, in the differenced specification, the vector $X_{k t-1}$ accounts for the potential differential effect of city characteristics on the relative location choice of the two groups.

If public housing supply is correlated with unobserved city-specific trends, estimates using the model of equation (2) and the difference-in-differences model of equation (3) should differ in an important way. We should also find a significant correlation between the location of immigrant without children and public housing, which will reflect the effect of the correlation with unobserved factors.

For the models of equation (2) and (3), we weight the second-step regression by the precision with which we estimate the sets of parameters in the first step. ${ }^{23}$

\section{Construction of the Instrument}

The fact that we use immigrants without children as a control group and estimate the differential response of those with children attenuates the risk of bias. However, previous estimates would still be biased if public housing were constructed in response to flows of immigrant families who are attracted by an unobserved factor that does not attract immigrants without children.

We address this problem by using in alternative specifications an instrument for equation (3), which predicts the dispersion of public housing in 1975 but should have no

${ }^{22}$ Denote by $P_{k t}$ and $P_{0 t}$ the probability of an individual with average characteristics $Z_{l k t}$ to choose urban area $k$ and the reference urban area indexed by 0 , respectively. We have (see Appendix) $\ln \frac{P_{k t}}{P_{0 t}}=\gamma_{k t}$. This implies that $\gamma_{k t}^{c}-\gamma_{k t}^{s}=\ln \frac{P_{k t}^{c}}{P_{k t}^{s}}-\ln \frac{P_{0 t}^{c}}{P_{0, t}^{s}}$. The second term is invariant across cities and it thus absorbed by the intercept.

${ }^{23}$ The appropriate weight is the inverse of the standard deviation of an observation. Assuming independent sampling, it is the inverse of the sum of the standard errors of the parameter estimates for the model of equation (3). 
direct impact on the location choices of immigrants. Our instrument relies on the previously discussed fact that large differences in the public housing stock result from the great variations in war damage across cities.

We construct a 'destruction index' by using differences in bombing intensity during the Second World War, reported by Florentin (1997) and Middlebrook and Everitt (1990) which we have adjusted to account for the fact that some cities were destroyed in the first part of the war in 1940. We calculate the sum of the number of bombings across municipalities of the urban area weighted by the share of the population in the municipality obtained from the 1936 Census. We take the square root of this sum to allow for a non-linear effect.

Figure 3 shows that there is a strong correlation between the share of public housing per household in 1975 and the intensity of destruction during the Second World War. In addition, cities affected by war destruction were located all over France. Many destroyed cities were in Normandy, Brittany or the North, but destructions were also great in the East (Saint-Etienne, Strasbourg, and Colmar) and the South of France (Toulon and Marseille) and in several cities in the West (Saint-Nazaire and Royan).

The validity of this instrument relies on the hypothesis that war destruction is not correlated with the unobservable determinants of the location choice of immigrants that are also correlated with the public housing supply. If war destruction had a persistent effect on the characteristics of bombed cities, this might violate the exclusion restriction of this instrument. ${ }^{24}$ However, the fact that the models use differences over time controls for the persistent effect of bombing on cities. Similarly, the fact that we also use the difference between the location choices of families with and without children removes the effect of unobserved factors that influence both groups similarly in a given time period.

\footnotetext{
${ }^{24}$ Most of the literature finds that even the most destructive bombings had little impact on city size or the distribution of economic activities (Davis and Weinstein, 2002, 2008), city growth (Brakman et al., 2004) or the poverty rate (Miguel and Roland, 2011).
} 


\section{Estimating the Effect of Public Housing on the Location Choices}

\section{Main Estimates}

We begin by presenting the estimates from the conditional logit model of equation (1) in Table 4. We estimate a separate model for the location choices of immigrants who arrived between 1962-1968 and 1975-1982 (and therefore are observed in the 1968 and the 1982 Census, respectively). For each Census year, the models are estimated separately for those in households with children and other immigrants.

As in previous studies, the results indicate that the share of the national group in the population is strongly positively correlated with the location choice. The estimates are between 0.42 and 0.48 and are quite similar across groups and periods. They predict that an increase of one standard deviation of this variable increases the probability to choose the 'average' urban area by between 42 to $47 \%$, which is a 1.3 to 1.4 p.p. increase in the initial probability of $3 \%$.

The estimates of other variables introduced in the model are more difficult to interpret. The effect of the average age of the group is unambiguously negative but varies across groups. The effect related to the average years of education of the group is also often negative, with the noticeable exception of couples with children, for which it is positive during the 1960s.

Table 5 and 6 presents the article's main results. In these specifications, the dependent variables are the group- and year-specific urban area-fixed effects, which measure the 'adjusted' probability of choosing an urban area estimated using the previous conditional logit model. Notice that to estimate the model, one urban area has to be dropped.

We start in Columns 1, 2 and 3 in Table 5 by presenting the baseline model of equation (2) estimated on couples with children. Column 1 presents estimates of a simple model without additional controls: we find a positive effect of public housing after the policy 
change but a large negative main effect of public housing. This last negative coefficient reflects mainly the fact, discussed before, that the distribution of public housing is negatively correlated with the share of immigrants in the location (Figure 2a). In Column 2 and 3, we include a full set of controls for city characteristics and the coefficient of the main effect of public housing becomes small and statistically insignificant.

Results in Columns 2 and 3 suggest that after 1975, the dispersion of public housing influenced significantly the location choices of new immigrants with children. Quantitatively, the effects appear strong. The estimates in Column 2 indicate that an increase of one standard deviation in the share of public housing units per household (approximately 9 p.p. over the sample period) increases the probability of choosing the 'average' urban area by approximately $12 \%$. In Column 3, we add to the model a full set of urban areas fixed effects which absorb the effect of constant over time city characteristics. If the regressions were simply picking up something unobserved that is related to the urban area, then the exclusion or addition of city fixed effects should change the coefficient on public housing considerably. If anything, the estimated effect is larger in this specification.

Because immigrants who are single should not respond to differences in the public housing supply, a direct estimate of the model on this group offers a simple test for how much the previous results are biased by unobserved confounding factors. Columns 4, 5 and 6 shows that public housing is not correlated with the location choices of immigrants without children after the reform, with each respective coefficient being small and statistically insignificant.

In Columns 7 to 9, we turn to evidence based on the difference-in-differences model of equation (3), where the dependent variable captures the differences in settlement patterns between new immigrants with and without children. As expected, since we found basically no effect of public housing on immigrants without children, these coefficients are very close to those obtained previously. In Column 9, the model includes both fixed effects and urban areas 
characteristics which accounts for the differential effects of city characteristics on the relative location of each groups. The estimates are barely affected.

Next, we repeat the same analysis with the difference-in-differences model separately on European and non-European immigrants in Table 6.25 Interestingly, the estimated coefficients are substantially larger for both groups in these specifications. This indicates there is a substantial heterogeneity of preferences between groups which is confirmed by an inspection of the coefficient of the main effect of public housing in columns (1) and (4) which varies widely. When we take into account these systematic differences, the estimated effect of public housing is multiplied by two. With parameter estimates close to 0.37 for Europeans and 0.50 for non-Europeans when a full set of controls is included in the model, these coefficients imply that the relative probability of choosing a location increases by between 40 to $50 \%$ when the public housing supply increases by one standard deviation; this translates into an increase of between 1.2 to 1.5 p.p. in the baseline probability of $3 \%$ of choosing the average urban area. Such estimated effects are quantitatively comparable to the effects of ethnic networks reported in Table 4.

We graphically present the variations underlying these results in Figure 4 for nonEuropean immigrants. While there is no observable correlation between public housing and the relative location choices for immigrants arrived in the 1962-68 period, there is a strong positive correlation between the two for those arrived in 1975-82, which is not driven by any particular outlier. In particular, La Rochelle from the sample does not practically affect the parameter estimates.

\section{Examining the Robustness to Alternative Specifications}

We investigate the robustness of our estimates in a series of alternative specifications in Tables 7 and 8 . To save space, we focus on the robustness of the difference-in-differences

${ }^{25}$ We estimate separate first stage models for European and non-European using Eq.

(1) to obtain the location probabilities used as dependent variables. 
model including fixed effects, and, as conducted previously, we report separate estimates for European and non-European immigrants.

In Panel 1 of Table 7, we account for the possibility that some endogeneity may remain in the public housing supply using the war destruction index previously described as an instrumental variable. The results from the IV estimates confirm the positive effect of public housing on the location choices of new immigrants that are married with children. The estimates tend to be quite similar to the corresponding OLS estimate for non-Europeans, while they are slightly lower for non-European immigrants. The first-stage Fisher test statistic indicates that the instrument is reasonably strong: with F-statistics close to 10 in all specifications, they pass the weak instrument test.

The model presented so far ignored any heterogeneity in the impact of public housing across immigrants with respect to characteristics such as education or age. ${ }^{26}$ However, we have observed in Table 1 that the characteristics of new immigrants with and without children tend to differ and have evolved over time. New immigrants with children tend to be older and more educated on average than those without children. In addition, the share of educated immigrants increases over time. If the response to public housing varies with the characteristics of immigrants, immigrants without children might be an invalid control group. Similarly, if immigrants that arrived in the 1960s are very different from those that arrived in the 1970s, our estimates might be affected by these compositional changes.

To address this issue, we adopt an approach inspired by the synthetic control method of Abadie et al. (2010) that we adapt to our context of a discrete choice model. Our method is to control for differences in characteristics across groups and over time by reweighting individual observations such that the weighted distribution of education and age is similar in

\footnotetext{
${ }^{26}$ As mentioned before, we cannot directly control for the effect of education or any other individual characteristics in the model because the education of an individual is invariant across cities and therefore cannot be identified (Train, 2003).
} 
both the control and treated groups and also during both periods of time. By keeping constant the composition over time and across groups, our estimates of the effect of public housing between and after the policy change are by definition not affected by changes in the distribution of immigrant characteristics over time or between groups.

In Panel 2, we use reference weights based on the distribution of the education and a of non-European immigrants in 1968 . We use 24 cells defined by the interaction between six age groups and four education groups. ${ }^{27}$ The results indicate that keeping constant the distribution of education and age does not change the coefficient in an important way with respect to the baseline specification. In Panel 3, we follow the same approach but use the distribution of the education and age of non-Europeans in 1982 as a reference instead. As observed in Panel C of Table 1, this group is more educated, which tends to put more weight on more educated immigrants. We obtain broadly similar results.

In Panels 4 and 5, we directly investigate the heterogeneity of the response to public housing for new immigrants with different education levels. In Panel 4, we restrict the sample to individuals with an education level strictly inferior to high school. We also observe positive and statistically significant coefficients for both groups with significantly larger coefficients for European immigrants. In contrast, estimates with high school and university graduates in Panel 5 are smaller and measured very imprecisely. Overall, there is much less evidence that the public housing supply influenced the location choices of the most educated immigrants.

To probe the possibility of reverse causality, Panel 1 of Table 8 reports the estimates of models that also include future measures of the public housing supply in 1990 using a dynamic version of equation (2):

\footnotetext{
${ }^{27}$ The groups of education are primary education, secondary education, high school and university graduates. The age groups are younger than 25, 25-29, 30-34, 35-39, 40-44, and older than 45. Notice that we also reweight the distribution of the characteristics of European immigrants using the distribution of non-European characteristics to derive whether differences between groups are due to differences in characteristics.
} 


$$
\hat{\gamma}_{k t}^{c}-\hat{\gamma}_{k t}^{s}=\delta_{82} p_{k, 75} e_{82}+\delta_{\text {lead }} p_{k, 90} e_{82}+\beta p_{k, t-1}+\Gamma_{k}+u_{k t}
$$

Including the lead terms in the model enables a direct test of endogenous shifts in the public housing supply following immigration. If the estimation of the lead coefficient $\delta_{\text {lead }}$ is significant and positive, this can be interpreted as evidence of reverse causality, while an estimate close to zero is consistent with the absence of such an effect. Reassuringly, for nonEuropean immigrants, the results indicate that a lagged public housing supply appears to have the highest impact on the location choice. For European immigrants, the results are more difficult to interpret: the coefficients on the lead terms are large and negative but statistically insignificant. While these tests are not definitive, they do provide some evidence that the relationship between changes in the public housing supply per capita and immigrant inflows is not primarily driven by reverse causality.

Next, we investigate how much our results depend on the inclusion of large cities, which attract a disproportionate share of immigrants, in the sample. In Panel 2, we find that excluding the 10 largest cities from the sample does not change the results much. In Panel 3, we repeat the same analysis by using an unweighted regression, while in Panel 4, we use weights obtained from a feasible GLS procedure assuming a heteroskedastic error structure across cities with no cross-sectional correlation. In these specifications, we find that the main results are barely affected.

Next, we examine the potential bias that could arise if the family status of immigrants responds to differences in the public housing supply. One important issue is that that fertility decisions might be influenced by the public housing supply. For instance, individuals without children might respond in anticipation to differences in public housing if they plan to have children in the future. We can test whether endogenous fertility responses to public housing drive the previous results by estimating the model with the subsample of immigrants with 
children born before the arrival of the immigrants in France. ${ }^{28}$ The results in Panel 5 present a reassuring picture: the parameter estimates are quite similar to those obtained previously for non-European immigrants while they are substantially larger for European immigrants.

In Panels 6 and 7, we test the robustness of our results to the use of different definitions of the control group. In Panel 6, we only include immigrants without children living as a couple in the control group. While these immigrants might be more similar than couples with children, they might react to public housing in anticipation. However, even if these estimates are a little more imprecise, they are consistent the previous results. In Panel 7, we only include singles in the control group. Singles are much less likely to be affected by public housing; however, they might not be attracted by the same factors as immigrants with children. Once again, our main conclusions remain unchanged even if the coefficients tend to be significantly larger in Panel 7.

Finally, in Panel 8, we include more recent data in the sample from the 1990 and 1999 Censuses. While we prefer evidence from a more limited period of time where unobserved urban area-level factors might not have changed too much before and after the policy change, these estimates are informative of whether the recent data also indicate a correlation between public housing supply and the location choice. We also find a positive impact of public housing on immigrants who arrived during the 1980s and the 1990s. For non-European immigrants, the coefficients on the more recent period are lower, especially in the 1990s where they are not statistically significant.

Taken together, these robustness checks suggest that the basic results are not driven by omitted variables. Although we cannot completely rule out the possibility of bias, the precise

\footnotetext{
${ }^{28}$ Because we have no information on the exact arrival year, the sample contains households where the age of the oldest child is superior to the period of time elapsed since the previous census in which the immigrant reported that he was not living in France.
} 
pattern observed in the data is difficult to reconcile with an explanation unrelated to the effect of public housing.

\section{Mechanisms behind the Causal Relationship: Housing Quality, Labour Market Outcomes and Public Housing}

The focus of our empirical effort thus far has been to establish an important and previously unrecognised pattern: that public housing influences the location choices of immigrants. We argued that this causal relationship may be explained by the fact that public housing is more attractive to immigrants than the available alternatives in the private housing market. We provide some evidence in this section that this mechanism is at work by first investigating whether new immigrants enjoy higher housing quality in locations with a higher supply of public housing.

Specifically, we compute urban area-level measures of the share of households living in an overcrowded home for new immigrants using the 1982 Census. Overcrowding indexes are calculated by the French statistical institute by dividing the number of individuals by the number of rooms in the house (see Appendix). For each group of immigrants and each urban area, we compute the share of immigrants living in an overcrowded and severely overcrowded home that we adjust to take into account the differences in group characteristics across cities..$^{29}$ Overcrowding was quite frequent for non-European immigrants: $46 \%$ of non-European male new immigrants married with children lived in an overcrowded home, as compared to only $16 \%$ of natives.

Panel A of Table 9 shows the results of a regression of our overcrowding indexes on the supply of public housing in the urban area. Row 1 shows that there is a strong negative

\footnotetext{
${ }^{29}$ The shares are adjusted by using the estimated residuals from a regression of the probability that a new immigrant lives in an overcrowded home on a quadratic function of age, years of education, the number of children and four dummies capturing the employment level.
} 
correlation between the share of the group living in overcrowded homes and the supply of public housing for both non-European and European immigrants. Our estimate suggests that an increase of one standard deviation in the public housing supply decreases the probability of living in an overcrowded home by approximately $4 \%$ for non-Europeans and $3 \%$ for Europeans.

In Row 2, we perform a simple placebo test by regressing the share of non-European immigrants in overcrowded housing in 1968 on the public housing supply in 1982. Recall that new immigrants did not have access to public housing during the 1960s. If we were just picking up urban area-specific factors unrelated to public housing that are persistent over time, then we should also find a positive relationship between the housing quality in 1968 and the public housing supply in 1982. The results reject this hypothesis and indicate that there is no significant correlation between the housing quality in 1968 and the future public housing supply in 1982: the coefficients are negative but relatively small and statistically insignificant.

In Row 3, we use the differences in the share of those living in overcrowded housing between 1982 and 1968 as a dependent variable. By differencing, we eliminate all common urban area-level factors that similarly influence the housing quality of European and nonEuropean new immigrants in both periods. We obtain negative coefficients that are relatively large but are measured imprecisely.

An important question is whether these improved housing conditions were obtained at the price of inferior labour market outcomes. In Panel B, we use the same methods to investigate the correlation between the (adjusted) employment outcomes of new immigrants and the public housing supply. We find some evidence in Row 1 that non-European new immigrants are more likely to be unemployed in cities with a larger share of public housing. The estimates indicate that an increase of one standard deviation in the public housing supply decreases the adjusted employment rate by approximately 3\% for non-Europeans. For 
European immigrants, the estimates are more inconclusive, with a positive parameter measured rather imprecisely. Row 2 indicates that no economically significant relationship is found between employment outcomes and the public housing supply in 1968 for both groups. In Row 3, using the difference between both periods, we find a negative coefficient for nonEuropean immigrant which is statistically significant while we find no effect on European immigrants.

In sum, the patterns in Table 9 provide compelling evidence that new immigrants are less likely to live in overcrowded housing in cities offering a larger supply of public housing. We also find some evidence of a negative correlation between employment outcomes and the public housing supply across cities for non-European immigrants, which is suggestive of the fact that these immigrants might face a trade-off between housing quality and employment outcomes.

\section{Concluding Remarks}

Our study has examined the effect of public housing on the location choices of immigrants across urban areas in France. The unique features of our dataset, which contains precise information on public housing and the location choices of approximately one-fourth of the new immigrants who arrived in France from 1962 to 1999, have allowed us to present new evidence regarding the determinants of the location choices of immigrants. The novelty of our analysis lies in part in our empirical strategy, which exploits differences in the location patterns across groups of immigrants over time following a policy change in public housing accessibility. Doing so enables us to more effectively control for unobserved urban areaspecific factors that might be correlated with differences in the public housing supply.

Our results reveal relatively robust evidence that differences in the availability of public housing have influenced the location choices of new immigrants with children, who disproportionately live in public housing. We estimate that an increase of one standard 
deviation in the number of public housing units per household (approximately 9\%) increases the probability of choosing the average urban area by approximately 1.2 p.p., from $3 \%$ to 4.2\%. We also find that there is a correlation between housing quality and the supply of public housing at the urban area level: new immigrants who are married with children are much less likely to live in an overcrowded home in locations with a higher supply of public housing.

Although there are key advantages to our empirical approach, there are some important caveats. First, we only capture the effect of public housing on the initial location choice. The subsequent location choices or mobility decisions of immigrants might also be influenced by public housing availability.

Second, the impact of public housing on the initial location choice is an important concern only if the initial location choice is persistent. If immigrants are subsequently mobile once they assimilate into their host society, the determinants of their initial location choices are not very important. However, public housing inhabitants and immigrants in particular are much less mobile than average (Gobillon, 2001). In addition, the share of non-European immigrants living in public housing does not decrease much with the time spent in France (Verdugo, 2011b). These elements suggest there is a significant risk that immigrants in public housing may be trapped in cities with unfavourable labour market prospects. This mismatch between labour demand and the location choices of some immigrant groups at the regional level might help explain a significant share of the high unemployment rate of immigrants in France (Decreuse and Schmutz, 2012).

\section{Appendix}

1. Additional details on the construction of the data 
Immigrants: As is conventional, an immigrant is defined as a foreign-born individual who is a non-citizen or a naturalised French citizen. We distinguish among 54 different countries of birth, which are always reported separately across censuses.

Urban areas: The boundaries of urban areas are kept constant across censuses by matching municipalities with the national municipality code. Each municipality has a unique administrative identifier held constant over time with very few exceptions, which have been accounted for. Arbitrarily, the main municipality of the urban area is defined as the most populated municipality of the area.

Public housing supply: We use the exhaustive dwelling files (100\% extract) from the 1982, 1990 and 1999 Censuses to compute the number of public housing units per urban area.

Urban areas wages and housing costs: The Population Census does not contain any information on income, wages or housing costs. We rely on alternative sources to compute two control variables for housing costs and wages. These data are not available at the urban area level but only at the regional level. There are 22 regions in France. Regional wages are estimated by using the residuals of a regression of log wages on education, a quadratic of potential experience, and 10 variables for industries. The data used to compute the average wage across regions come from the 1970 and 1977 FQP survey and from the French labour force survey (LFS) of 1982 and 1990. Housing Costs are estimated by using the 1973, 1978 1984, and 1992 housing surveys and are matched with 1968, 1975, 1982 and 1990 Census data, respectively. We use the average rent for a dwelling with two bedrooms.

Overcrowded housing: The definition follows the French Statistical Institute. For each household, there should be a living room, a bedroom for each couple, a room for each single older than 19 years, a room for 2 children if they are of the same sex or a room for each child if they are of different sexes. If one room is missing, the dwelling is defined as moderately 
overcrowded. If more than one room is missing, the dwelling is defined as severely overcrowded.

Waiting times from the 1996 and 2002 Housing Condition Surveys (Figure 1): We focus on new public housing inhabitants living in urban areas with more than 100,000 inhabitants from the housing Census. For reasons of confidentiality, these surveys do not contain information on the urban areas. Four sparsely populated regions with fewer than 15 individual observations have been aggregated with the neighbouring regions. The final sample size is 2,490 observations.

\section{Interpretation of parameters of conditional logit with standardised}

\section{variables}

We show that the parameters of a conditional logit where the predictors have been standardised have a simple interpretation. Suppose the true model is $U_{i j}=x_{j} \beta+e_{i j}$ for individual i and location j. Denote by $z_{j}^{k}=\frac{x_{j}^{k}-\bar{x}^{k}}{\sigma_{x^{k}}}$ the standardised variable of the predictor $k$ for alternative $j ; \bar{x}^{k}$ and $\sigma_{x^{k}}$ indicate the average and the standard deviation of the predictor $k$ over the initial choice set, respectively. Because only differences in utility matter (see Train, 2003, p. 23), the model can be rewritten as $Z U_{i j}=z_{j} \gamma+e_{i j}$, where the relation between $\beta$ and $\gamma$ is given by $\beta_{k}=\frac{\gamma_{k}}{\sigma_{x^{k}}}$ for all predictors $k$. Let us consider the counterfactual probability of choosing two alternatives not included in the initial choice set. The first is the 'average' urban area for which the characteristics are equal to the average of the $J$ pre-existing alternatives. The second is identical to the 'average' urban area except that the characteristic $l$ is equal to the average plus one standard deviation. When the predictors have been standardised, the characteristics of the average urban area are a vector of zero, whereas the vector of characteristics of the other additional alternative $z$ is $z^{l}=1$ and $z^{k}=0$ 
for $\forall k \neq l$. The probability $P$ of the average alternative is equal to $P=\frac{1}{1+\exp \left(\gamma_{l}\right)+\sum_{j}^{J} \exp \left(z_{j} \gamma\right)}$ whereas the probability $P_{l}$ for the other alternative is $P_{l}=\frac{\exp \left(\gamma_{l}\right)}{1+\exp \left(\gamma_{l}\right)+\sum_{j}^{J} \exp \left(z_{j} \gamma\right)}$. This implies $\frac{P_{l}}{P}=\exp \left(\gamma_{l}\right) \quad$ and $\log P_{l}-\log P=\gamma_{l}$. The parameter $\gamma_{l}$ is equal to the log difference between the probability of choosing the average urban area when the predictor $l$ is higher by one standard deviation and the probability of choosing the 'average' urban area. 


\section{References}

Abadie, Alberto, Alexis Diamond and Jens Hainmueller (2010), 'Synthetic control methods for comparative case studies: Estimating the effect of california's tobacco control program', Journal of the American Statistical Association 105(490).

Algan, Yann, Camille Hémet and David Laitin (2011), Diversity and Public Good in a Republican Setting.

Aydemir, Abdurrahman and George J. Borjas (2011), 'Attenuation bias in measuring the wage impact of immigration', Journal of Labor Economics 29(1): 69-112.

Bartel, Ann P. (1989), 'Where do the new u.s. immigrants live?', Journal of Labor Economics 7(4), 371-391.

Baum-Snow, Nathaniel and Justin Marion (2009), 'The effects of low income housing tax credit developments on neighborhoods', Journal of Public Economics 93(5-6): 654-666.

Bayer, Patrick, Fernando V. Ferreira and Robert McMillan (2007), 'A unified framework for measuring preferences for schools and neighborhoods', Journal of Political Economy 115(4): 588-638.

Bayer, Patrick and Robert McMillan (2012), 'Tiebout sorting and neighborhood stratification', Journal of Public Economics 96(11): 1129-1143.

Berry, Steven, James Levinsohn and Ariel Pakes (1995), 'Automobile prices in market equilibrium', Econometrica 63(4): 841-90.

Berry, Steven, Oliver Bruce Linton and Ariel Pakes (2004), 'Limit theorems for estimating the parameters of differentiated product demand systems', Review of Economic Studies 71: 613-654.

Borjas, George J. (1999), 'Immigration and welfare magnets', Journal of Labor Economics 17(4): 607-637.

Borjas, George J. (2001), 'Does immigration grease the wheels of the labor market?', Brookings Papers on Economic Activity (1): 69-119.

Bouvard, Laurence, Pierre-Philippe Combes, Bruno Decreuse, Benoît Schmutz Morgane Laouénan and Alain Trannoy (2009), 'Géographie du chômage des personnes d'origine africaine: Une discrimination sur le marché du logement ?', Revue Française d'Économie 23(1): 8-56.

Brakman, Steven, Harry Garretsen and Marc Schramm (2004), 'The strategic bombing of german cities during world war ii and its impact on city growth', Journal of Economic Geography 4(2): 201-218.

Cascio, Elizabeth U. and Ethan G. Lewis (2011), 'Cracks in the melting pot: Immigration, school choice, and segregation', American Economic Journal: Applied Economics .

Currie, Janet and Aaron Yelowitz (2000), 'Are public housing projects good for kids?', Journal of Public Economics 75(1): 99-124.

Davis, Donald R. and David E. Weinstein (2008), 'A search for multiple equilibria in urban industrial structure', Journal of Regional Science 48(1): 29-65.

Davis, Donald R. and David Weinstein (2002), 'Bones, bombs, and break points: The geography of economic activity', American Economic Review 92(5): 1269-1289.

Decreuse, Bruno and Benoit Schmutz (2012), 'Residential mobility and unemployment of african immigrants in france: a calibration approach', Annales d'Économie et de Statistique 107-108.

Desplanques, Guy and Nicole Tabard (1991), 'La localisation de la population étrangère', Economie et Statistiques 242 : 51-62.

Donald, Stephen G. and Kevin Lang (2007), 'Inference with difference-in-differences and other panel data', The Review of Economics and Statistics 89(2): 221-233. 
Durif, Pierre and Olivier Marchand (1975), 'Les locataires des hlm en 1973', Économie et Statistique 73 : 3-20.

Florentin, Eddy (1997), Quand les Alliés bombardaient la France, 1940-1945, Paris, Perrin.

Giorgi, Giacomo De and Michele Pellizzari (2009), 'Welfare migration in europe', Labour Economics 16(4): $353-363$.

Gobillon, Laurent (2001), 'Emploi, logement et mobilité résidentielle', Economie et statistique 349(1): 77-98.

Guillouet, Jean-Jacques and Philippe Pauquet (2011), 'La demande de logements locatifs sociaux en Île-defrance en 2010', Institut d'Aménagement et d'Urbanisme d'Île de France .

Jacob, Brian A. (2004), 'Public housing, housing vouchers, and student achievement: Evidence from public housing demolitions in chicago', American Economic Review 94(1): 233-258.

Jaeger, David A. (2001), Local Labor Markets, Admission Categories, and Immigrant Location Choice. Hunter College and Graduate Center.

Jaeger, David A. (2008), 'Green Cards and the Location Choices of Immigrants in the United States, 19712000', Research in Labor Economics 27(1): 131-183.

Jayet, Hubert and Nadiya Ukrayinchuk (2007), 'La localisation des immigrants en France: Une première approche', Revue d'économie régionale et urbaine 4(11): 625-649.

Kaushal, Neeraj (2005), 'New immigrants' location choices: Magnets without welfare', Journal of Labor Economics 23(1): 59-80.

Le Blanc, David, Anne Laferrère and Rémy Pigois (1999), 'Les effets de l'existence du parc hlm sur le profil de consommation des ménages', Économie et Statistique 8(328): 37-59.

Lequin, Yves (2006), Immigrés en ville, in Y.Lequin, ed., 'Histoire des Étrangers et de l'Immigration en France', Larousse, pp. 408-429.

Middlebrook, Martin and Chris Everitt (1990), The Bomber Command war diaries: an operational reference book, 1939-1945, Penguin Books.

Miguel, Edward and Gérard Roland (2011), 'The long-run impact of bombing vietnam', Journal of Development Economics 96(1): 1 - 15 .

Mincer, Jacob (1978), 'Family migration decisions', Journal of Political Economy 86(5): 749-73.

Moretti, Enrico (2011), Chapter 14 - local labor markets, in O.Ashenfelter and D.Card, eds, 'Handbooks in Economics Handbook of Labor Economics, Vol 4B', Vol. 4, Part B of Handbook of Labor Economics, Elsevier, pp. $1237-1313$.

Musterd, Sako and Rinus Deurloo (1997), 'Ethnic segregation and the role of public housing in Amsterdam', Tijdschrift voor economische en sociale geografie 88: 158-168.

Pinçon, Michel (1976), Les HLM: structure sociale de la population logée. Agglomération de Paris - 1968, Centre de sociologie urbaine, Paris.

Pischke, Jorn-Steffen and Johannes Velling (1997), 'Employment effects of immigration to germany: An analysis based on local labor markets', The Review of Economics and Statistics 79(4): 594-604.

Priemus, Hugo and Frans Dieleman (2002), 'Social housing policy in the European Union: past, present and perspectives', Urban Studies 39(2): 191-200.

Rutter, Jil and Maria Latorre (2008), Social housing allocation and immigrant communities, Equality and Human Rights Commission. 
Schor, Ralph (1996), Histoire de l'immigration en France de la fin du XIXe siècle a nos jours, Armand Colin. Stébé, Jean-Marc (2007), Le logement social en France, PUF.

Train, Kenneth (2003), Discrete Choice Methods with Simulation, Cambridge University Press.

Trevien, Corentin (2013), 'Habiter en hlm: quels avantages, quelles différences?', INSEE Analyses 10.

Verdugo, Gregory (2009), Les immigrés et le marché du travail en france: quelques éléments descriptifs, in 'Immigrations, Qualifications et Marché du Travail', La Documentation Francaise, pp. 115-130.

Verdugo, Gregory (2011a), 'Fragmentation urbaine et chocs économiques : deux déterminants de l'offre de logement sociaux en France', Économie et Statistiques (446): 3-24.

Verdugo, Gregory (2011b), 'Public Housing and Residential Segregation of Immigrants in France, 1968-1999', Population-E (1).

Voldman, Danièle (1997), La reconstruction des villes françaises de 1940 à 1954: histoire d'une politique, L'Harmattan Edition.

Weil, Patrick (2005), La République et sa diversité: Immigration, intégration, discriminations, Seuil. 


\section{Figure 1: Waiting Times and Public Housing Supply across Regions}

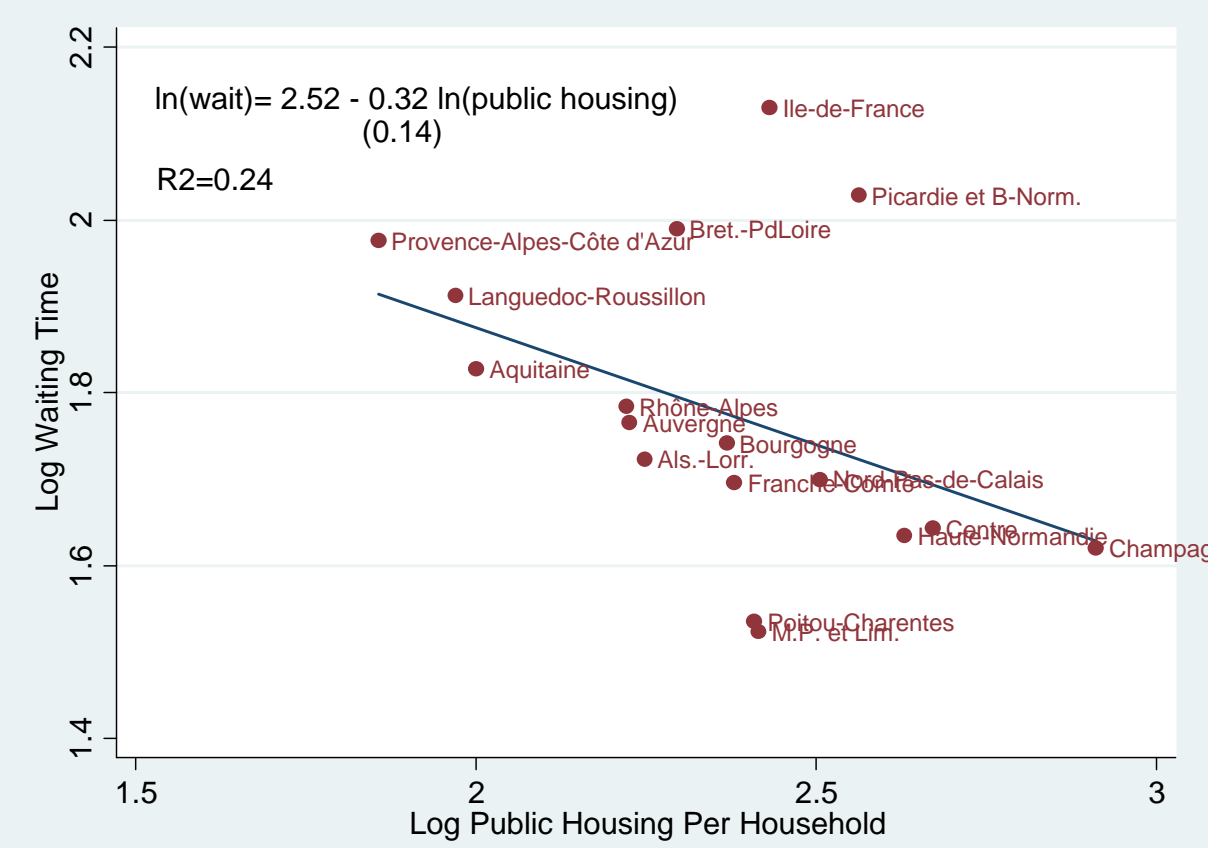

Notes: the Figure plots the relationship between public housing per household and waiting times for public housing across French regions. Sources: Waiting times for public housing from the 1996 and the 2002 Housing Condition surveys. Public Housing per household from the 1999 Census.

Figure 2: Public Housing Supply and Initial Immigrant Stock in 1968

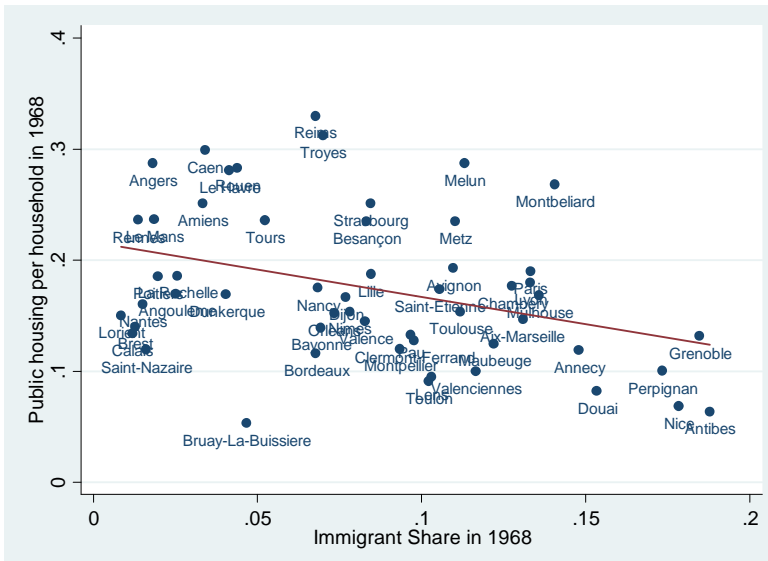

(a) Observed correlation

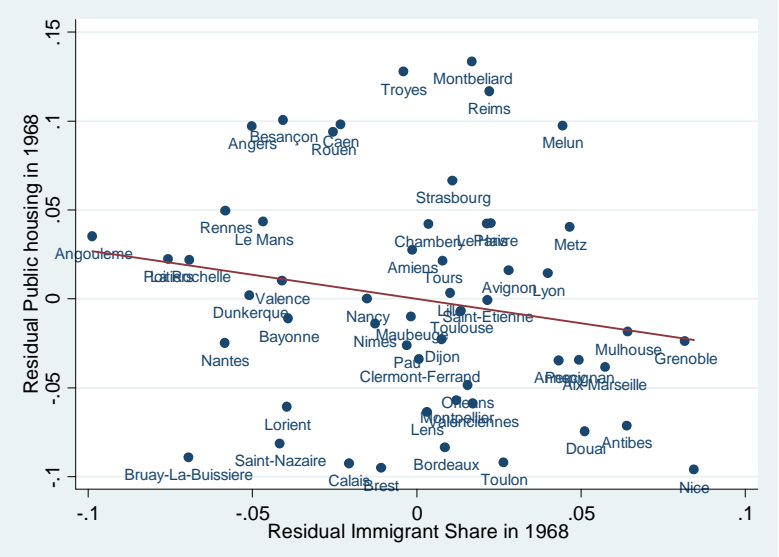

(b) Correlation controlling for war destruction

Notes: The panel (a) plots the relationship between public housing per household and the share of immigrants in the population in 1968. The panel (b) plots the residual of a regression of these two variables on the war destruction index. Sources: Census of Population. 


\section{Figure 3: Public Housing Supply in 1975 and War Destructions}

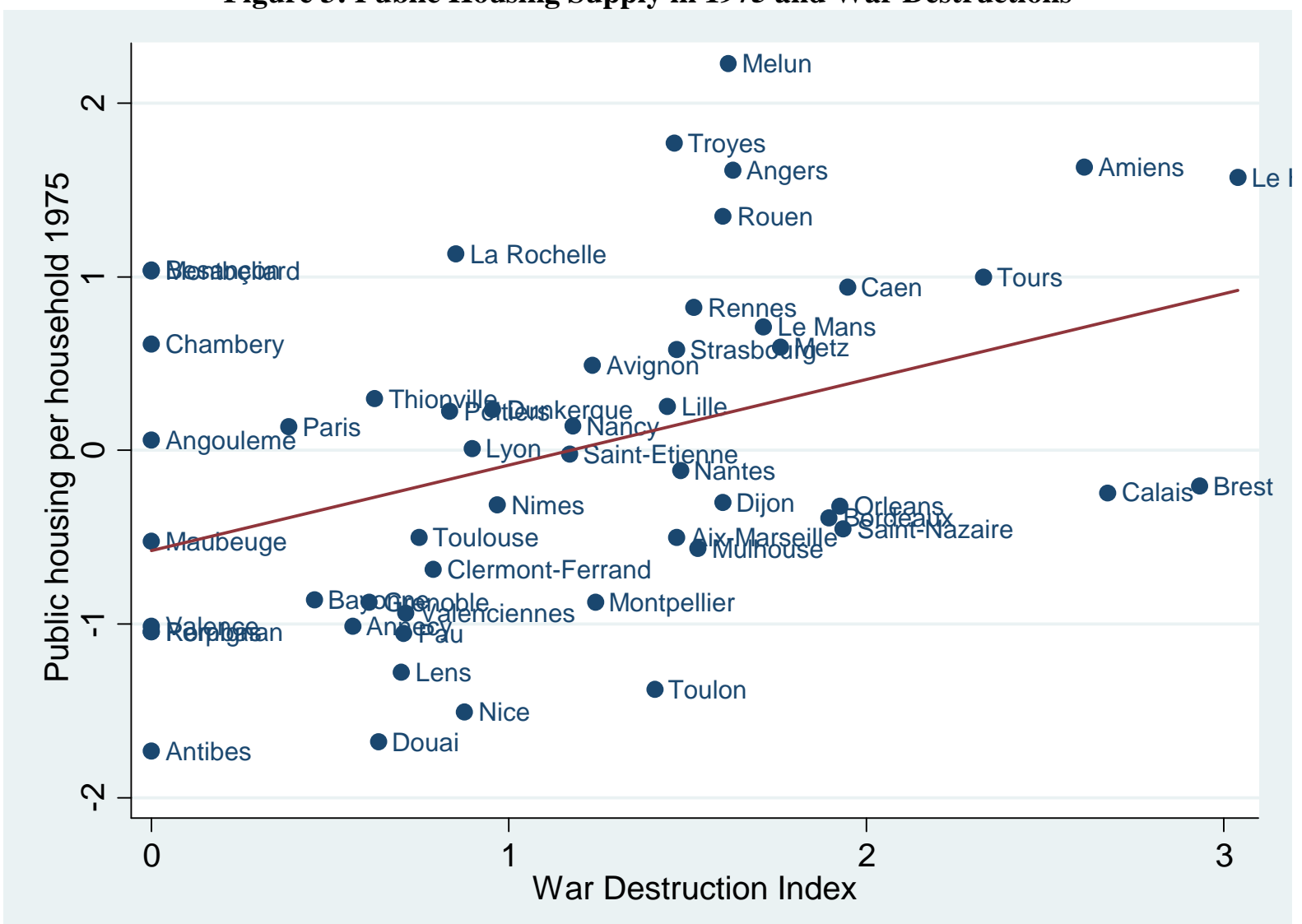

Notes: the Figure plots the relationship between public housing per household in 1975 and the destruction index. The Destruction Index is the square root of the number of bombings during the Second World War in a given municipality of the urban area weighted by the population share of this municipality in 1936. 
Figure 4: Public Housing Supply and the differential location choice for non-European immigrants with and without children

A -Arrival 1962-1968

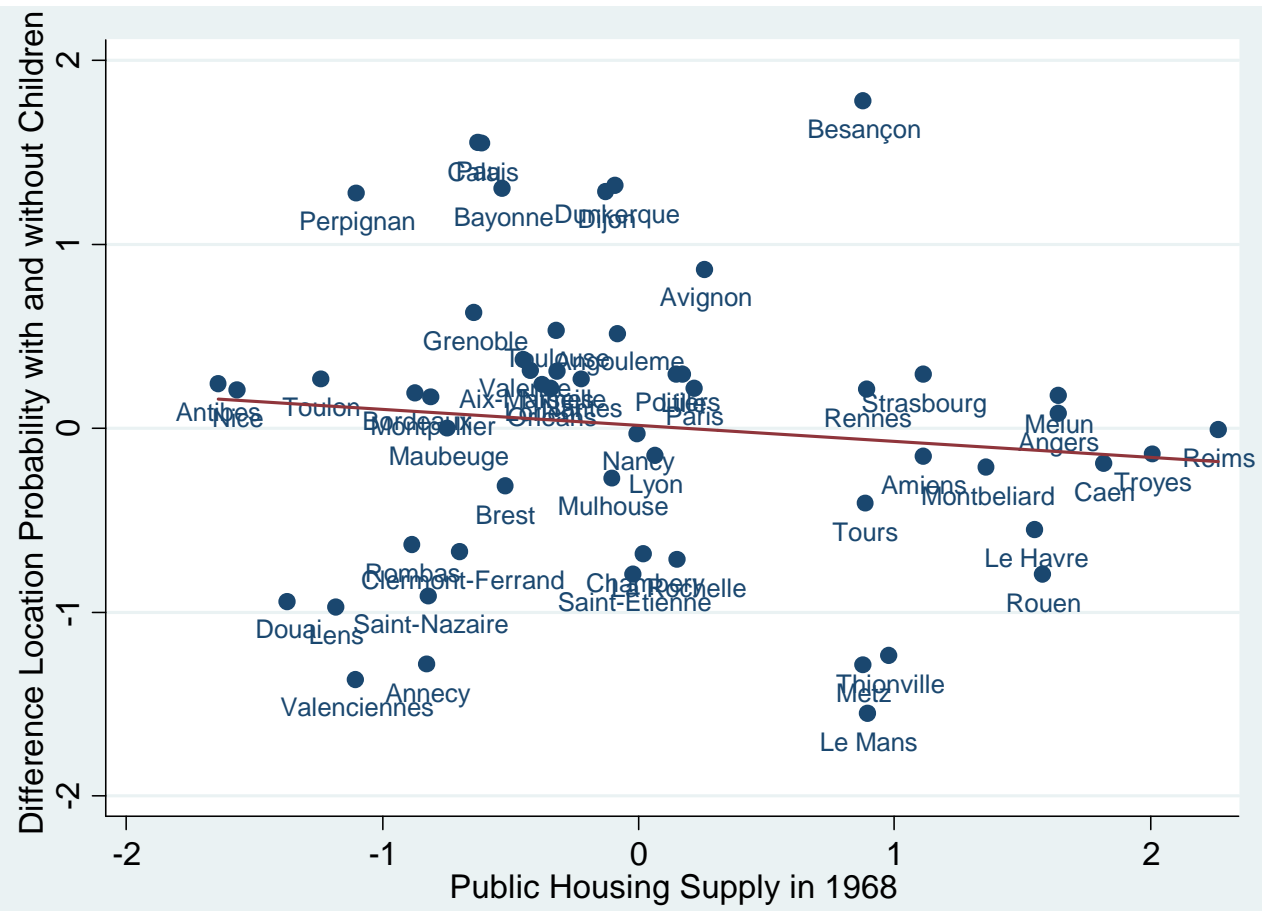

B- Arrival 1975-1982

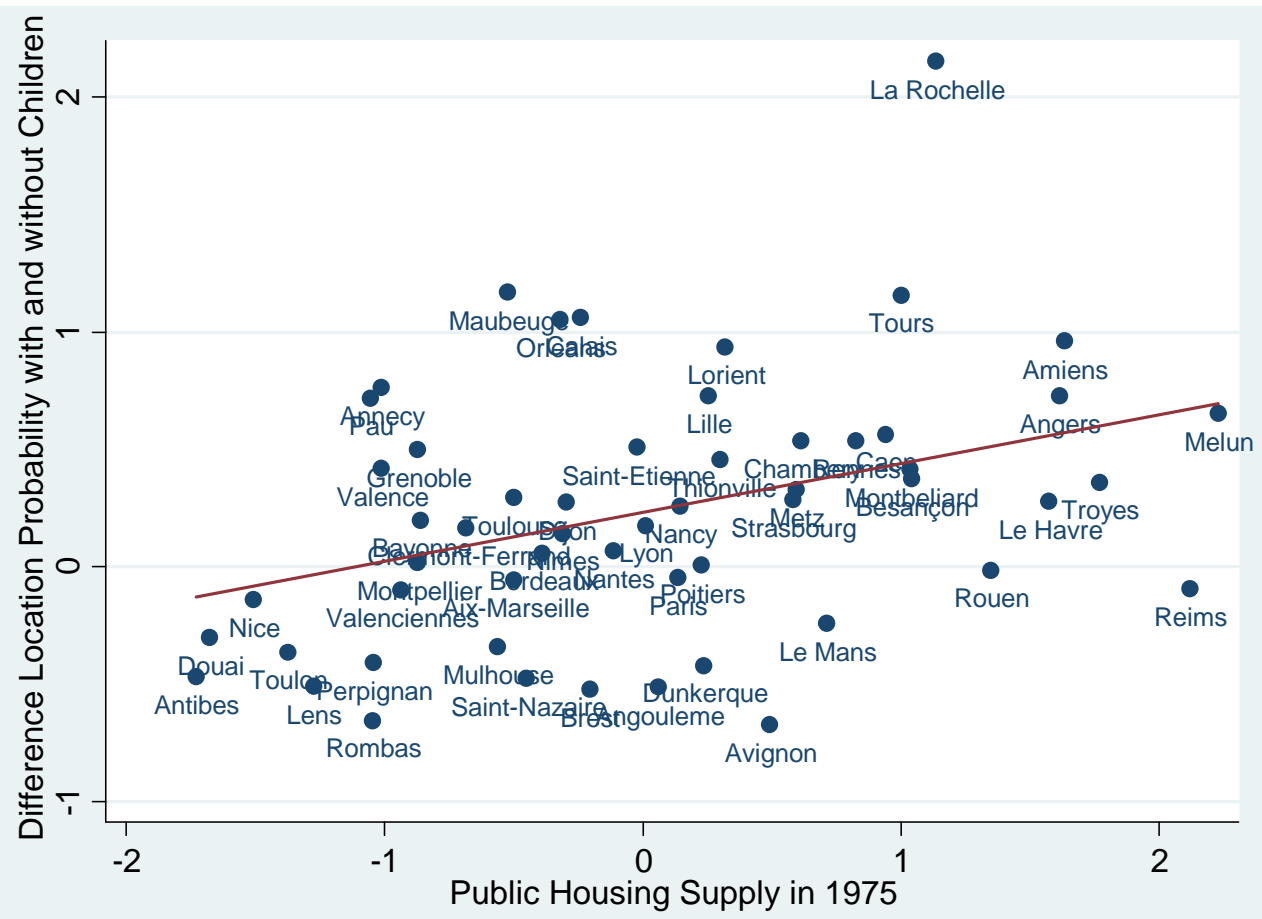

Notes: the Figure plots the relationship between centered differences in location choice of nonEuropean new immigrants married with and without children and public housing per household. Location probabilities are estimated using the conditional logit model of equation (1). Panel A uses arrivals during the period 1962-1968 while panel B uses arrival during the period 1975-1982. Public Housing per Household is normalized to have an average of zero and a standard deviation of one in each year. 
Table 1: New Immigrants and Public Housing Supply in France 1968-1999

\begin{tabular}{|c|c|c|c|c|c|c|}
\hline \multicolumn{7}{|c|}{ A. New Immigrants Inflows in France 1968-1999 } \\
\hline Arrival Period & $1962-68$ & $1968-75$ & $1975-82$ & & 1982-90 & $1990-99$ \\
\hline $\begin{array}{l}\text { Total Number } \\
\text { (in thousands) }\end{array}$ & 915 & 1053 & 707 & & 663 & 689 \\
\hline Number per year & 152 & 150 & 101 & & 95 & 77 \\
\hline \multicolumn{7}{|c|}{ B. Male new immigrant characteristics } \\
\hline & \multicolumn{2}{|c|}{ Non-Europeans } & \multicolumn{4}{|c|}{ Europeans } \\
\hline & with children & $\begin{array}{l}\text { without } \\
\text { children }\end{array}$ & with childre & & with & children \\
\hline \multicolumn{7}{|c|}{ Arrivals 1962-1968 } \\
\hline $\begin{array}{l}\text { Share High-School } \\
\text { graduates }\end{array}$ & 14.5 & 12.9 & & .8 & \multicolumn{2}{|c|}{5.5} \\
\hline Average age & 39.2 & 31.2 & & .7 & \multicolumn{2}{|c|}{32.2} \\
\hline \multicolumn{7}{|c|}{ Arrivals 1975-1982 } \\
\hline $\begin{array}{l}\text { Share High-School } \\
\text { graduates }\end{array}$ & 27.2 & 20.2 & & .5 & \multicolumn{2}{|c|}{29.5} \\
\hline Average age & 37.4 & 32.7 & & .4 & \multicolumn{2}{|c|}{33.2} \\
\hline \multicolumn{7}{|c|}{ C. Estimated Changes in Public Housing 1968-1999 } \\
\hline \multirow[t]{2}{*}{ Year } & PH Units & $\mathrm{Nb}$ per & Pct Change & & & $\mathrm{PH}$ \\
\hline & $\begin{array}{r}\text { Stock (in } \\
\text { thousands) }\end{array}$ & years & & & \multicolumn{2}{|c|}{ per Household } \\
\hline 1945 & 275 & & & & & \\
\hline 1968 & 1395 & & & & & $17 \%$ \\
\hline 1975 & 2239 & 121 & & 50 & & 25 \\
\hline 1982 & 2725 & 69 & & 22 & & 27 \\
\hline 1990 & 3093 & 46 & & 14 & & 30 \\
\hline
\end{tabular}

Notes: New immigrants are immigrants who declared to have been abroad during the previous census year. In panel C, only primary residences are included in the calculations. $P H$ per household reports respectively the average of the public housing supply per household across the 57 cities with more than 100000 inhabitants in 1990. Author's tabulations from 1999 Census of Housing and the 1968, 1975, 1982, 1990 and 1999 Censuses of Population. 
Table 2: Major Urban Areas Characteristics in 1990

\begin{tabular}{|l|r|r|r|r|r|}
\hline Urban area & $\begin{array}{c}\text { Total } \\
\text { Population }\end{array}$ & $\begin{array}{c}\text { Public Housing } \\
\text { per Household }\end{array}$ & $\begin{array}{c}\text { Immigrants to } \\
\text { Population }\end{array}$ & $\begin{array}{c}\text { Share of New } \\
\text { Immigrants }\end{array}$ & $\begin{array}{c}\text { Share } \\
\text { of Natives }\end{array}$ \\
\hline Paris & 9316 & $28 \%$ & $19.3 \%$ & $51.8 \%$ & $25.5 \%$ \\
\hline Lyon & 1262 & 21.9 & 14.7 & 3.5 & 3.5 \\
\hline Aix-Marseille & 1230 & 27.6 & 11.6 & 2.5 & 3.4 \\
\hline Lille & 959 & 31.9 & 9.8 & 1.7 & 2.6 \\
\hline Bordeaux & 696 & 23.7 & 7.6 & 1.4 & 2 \\
\hline Toulouse & 649 & 21.2 & 10.1 & 1.6 & 1.9 \\
\hline Nice & 517 & 12.5 & 13.8 & 1.6 & 1.4 \\
\hline Nantes & 495 & 25.0 & 3.8 & 0.6 & 1.5 \\
\hline Toulon & 437 & 16.0 & 8.9 & 0.5 & 1.2 \\
\hline Grenoble & 404 & 18.9 & 15.8 & 1.1 & 1.1 \\
\hline Strasbourg & 387 & 29.2 & 14.4 & 1.6 & 1.1 \\
\hline Rouen & 380 & 41.4 & 6.7 & 0.6 & 1.1 \\
\hline Valenciennes & 338 & 28.6 & 6.5 & 0.3 & 0.9 \\
\hline Antibes & 335 & 10.2 & 15.5 & 1.3 & 0.9 \\
\hline Nancy & 329 & 28.6 & 7.7 & 0.6 & 0.9 \\
\hline Lens & 323 & 22.0 & 4.2 & 0.1 & 0.9 \\
\hline
\end{tabular}

Notes: Only primary residence and inhabited housing are included in the calculations. In other columns, the population is restricted to men and women between 16 and 60 not in school and not in the military. Sources: 1990 Census. Author's calculation. 
Table 3: Share Living in Public Housing among Different Groups

\begin{tabular}{|l|c|c|c|}
\hline \multicolumn{4}{|c|}{ A. Participation rates per Nationality } \\
\hline Natives & 1982 & 1990 & 1999 \\
\hline Immigrants & $13.6 \%$ & $14.0 \%$ & $15.7 \%$ \\
\hline New Immigrants & 22.9 & 25.8 & 30.6 \\
\hline Share of Immigrants in Public Housing from \\
\hline Europe & $16.0 \%$ & $15.8 \%$ & $16.3 \%$ \\
\hline Africa & 33.1 & 39.1 & 46.4 \\
\hline Algeria & 34.8 & 42.5 & 49.7 \\
\hline Morocco & 37.3 & 43.1 & 48.3 \\
\hline Tunisia & 27.6 & 43.1 & 39.2 \\
\hline \multicolumn{4}{|c|}{ B. Participation Rates of Male New Immigrants } \\
\hline Education and Household Status in 1982 \\
\hline Married with children & Inferior to High- & At least High-School \\
School & Graduates \\
\hline Non-European & 43.1 & 26.8 \\
\hline European & 20.4 & 9.7 \\
\hline Other immigrants & 10.6 & \\
\hline Non-European & 8.7 & 13.3 \\
\hline European & \\
\hline
\end{tabular}

Source: 1982, 1990 and 1999 Censuses. Author's tabulations. 
Table 4: Conditional Logit Estimation Results:

Location choice of new immigrants across 57 cities

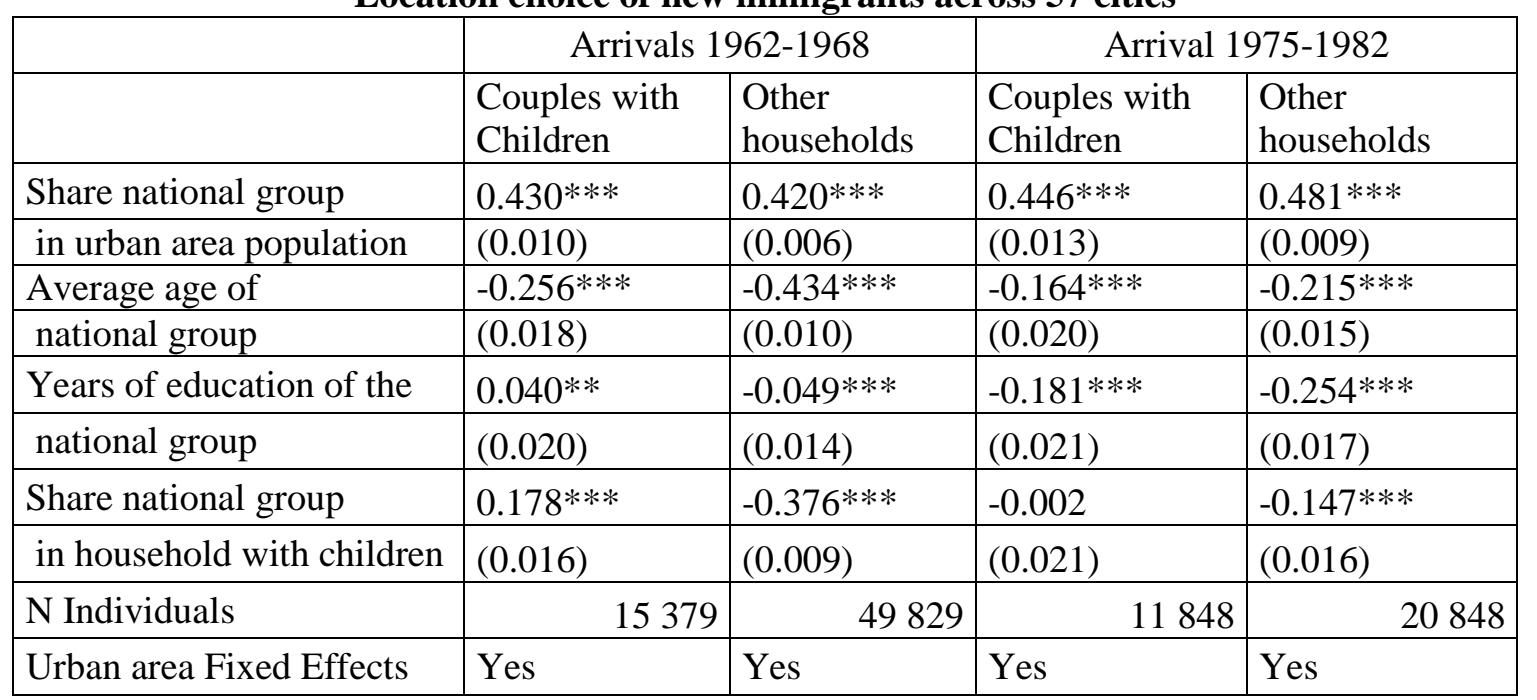

Notes: Within each panel, each column presents estimates of a separate conditional logit model on the indicated variable. The dependant variable is the choice of one of 57 cities. Each model includes urban area fixed effects. Only male new immigrants are included in the sample. For each arrival period, the model is estimated separately for individuals living as couples with children and other individuals. Robust heteroscedastic standard errors are reported in parenthesis.

Statistically significant * at the .10 level; ** at the .05 level; *** at the .01 level. 
Table 5: The Effect of Public Housing on the Location Choice of Immigrants

\begin{tabular}{|c|c|c|c|c|c|c|c|c|c|}
\hline \multicolumn{10}{|c|}{ Arrival $1962-68$ and $1975-1982,57$ cities } \\
\hline & (1) & (2) & (3) & (4) & $(5)$ & (6) & (7) & $(8)$ & (9) \\
\hline & \multicolumn{3}{|c|}{ Couples with Children } & \multicolumn{3}{|c|}{ Other Households } & \multicolumn{3}{|c|}{$\begin{array}{c}\text { Difference (Couples with } \\
\text { Children - Others Immigrants) }\end{array}$} \\
\hline $\begin{array}{l}\text { Public } \\
\text { Housing(75) }\end{array}$ & $0.136^{* *}$ & $0.119^{*}$ & $0.183 * * *$ & 0.082 & 0.000 & -0.023 & 0.112 & $0.147^{*}$ & $0.206^{* *}$ \\
\hline x Arrival 75-82 & $(0.063)$ & $(0.070)$ & $(0.068)$ & $(0.101)$ & $(0.097)$ & $(0.102)$ & $(0.081)$ & $(0.079)$ & $(0.091)$ \\
\hline \multirow[t]{2}{*}{$\begin{array}{l}\text { Public Housing } \\
(\mathrm{t}-1)\end{array}$} & $-0.294 * * *$ & -0.035 & 0.098 & $-0.319 * * *$ & 0.067 & 0.085 & 0.012 & -0.049 & 0.042 \\
\hline & $(0.104)$ & $(0.127)$ & $(0.177)$ & $(0.094)$ & $(0.111)$ & $(0.294)$ & $(0.072)$ & $(0.071)$ & $(0.324)$ \\
\hline \multirow[t]{2}{*}{ Share Immigrants } & & $0.633 * * *$ & $0.516^{* *}$ & & $0.654 * * *$ & $1.212 * * *$ & & 0.018 & $-0.626^{*}$ \\
\hline & & $(0.201)$ & $(0.241)$ & & $(0.171)$ & $(0.397)$ & & $(0.066)$ & $(0.329)$ \\
\hline \multirow[t]{2}{*}{$\begin{array}{l}\text { Share } \\
\text { Manufacturing }\end{array}$} & & $-0.311 * *$ & 0.073 & & -0.082 & -0.045 & & $-0.166 * * *$ & 0.17 \\
\hline & & $(0.127)$ & $(0.261)$ & & $(0.118)$ & $(0.535)$ & & $(0.061)$ & $(0.472)$ \\
\hline \multirow[t]{2}{*}{ Log population } & & $0.006 * * *$ & $0.116^{* *}$ & & $0.006 * * *$ & $0.179 * *$ & & 0.000 & -0.056 \\
\hline & & $(0.001)$ & $(0.054)$ & & $(0.001)$ & $(0.070)$ & & $(0.000)$ & $(0.047)$ \\
\hline \multirow[t]{2}{*}{ Average wage } & & 0.021 & -0.113 & & 0.068 & -0.150 & & -0.082 & 0.048 \\
\hline & & $(0.140)$ & $(0.124)$ & & $(0.130)$ & $(0.215)$ & & $(0.057)$ & $(0.175)$ \\
\hline \multirow[t]{2}{*}{ Average rent } & & -0.047 & -0.010 & & -0.116 & -0.011 & & 0.075 & 0.009 \\
\hline & & $(0.122)$ & $(0.104)$ & & $(0.114)$ & $(0.184)$ & & $(0.060)$ & $(0.119)$ \\
\hline \multirow[t]{2}{*}{$\begin{array}{l}\text { Unemployment } \\
\text { rate }\end{array}$} & & 0.128 & 0.120 & & $0.250 * *$ & 0.150 & & $-0.073 *$ & -0.027 \\
\hline & & $(0.104)$ & $(0.082)$ & & $(0.104)$ & $(0.125)$ & & $(0.044)$ & $(0.124)$ \\
\hline $\begin{array}{l}\text { Urban area Fixed } \\
\text { Effects }\end{array}$ & No & No & Yes & No & No & Yes & No & No & Yes \\
\hline $\mathrm{N}$ & 112 & 112 & 112 & 112 & 112 & 112 & 112 & 112 & 112 \\
\hline
\end{tabular}

Notes: In columns 1-6, the dependant variable is the log of the adjusted location probability of choosing one of the 56 urban areas with respect to the reference urban area. This probability was estimated using a separate conditional logit model for each group and year. In columns 7-9, the dependent variable is the difference between the adjusted probability for new immigrants with children and other new immigrants. Each regression is weighted using the inverse of the standard deviation of the estimates of the dependant variable. See text for details. Standard errors clustered at the urban area level are reported in parenthesis.

Statistically significant $*$ at the .10 level; $* *$ at the .05 level; *** at the .01 level. 
Table 6: European and non-European immigrants

\begin{tabular}{|c|c|c|c|c|c|c|}
\hline \multicolumn{7}{|c|}{ Arrival 1962-68 and 1975-1982, 57 cities } \\
\hline \multicolumn{7}{|c|}{ Dependent variable: Difference (Couples with Children - Others Immigrants) } \\
\hline & $(1)$ & $(2)$ & (3) & (4) & $(5)$ & $(6)$ \\
\hline & \multicolumn{3}{|c|}{ Non-European Immigrants } & \multicolumn{3}{|c|}{ European Immigrants } \\
\hline Public Housing(75) & $0.465^{* *}$ & $0.489 * *$ & $0.496 * *$ & $0.347 * * *$ & $0.384 * * *$ & $0.369 * * *$ \\
\hline $\mathrm{x}$ Arrival 75-82 & $(0.222)$ & $(0.243)$ & $(0.211)$ & $(0.088)$ & $(0.110)$ & $(0.101)$ \\
\hline \multirow[t]{2}{*}{ Public Housing(t-1) } & -0.051 & 0.027 & -0.342 & $-0.242 * * *$ & -0.009 & -0.186 \\
\hline & $(0.088)$ & $(0.130)$ & $(0.610)$ & $(0.051)$ & $(0.098)$ & $(0.462)$ \\
\hline Additional covariates & No & Yes & Yes & No & Yes & Yes \\
\hline $\begin{array}{l}\text { Urban area Fixed } \\
\text { Effects }\end{array}$ & No & No & Yes & No & No & Yes \\
\hline $\mathrm{N}$ & 112 & 112 & 112 & 112 & 112 & 112 \\
\hline
\end{tabular}

Notes: In each column, the dependent variable is the difference in the log adjusted location probability between new immigrants with children and other new immigrants. This probability was estimated using a separate conditional logit model for each group and year. Each regression is weighted using the inverse of the standard deviation of the estimates of the dependant variable. Standard errors clustered at the urban area level are reported in parenthesis.

Statistically significant * at the .10 level; ** at the .05 level; *** at the .01 level. 
Table 7: Further Evidence on the Effect of Public Housing on the Location Choice of Immigrants

\begin{tabular}{|l|l|l|}
\hline \multicolumn{3}{|c|}{ Dependant variable: } \\
\hline \multicolumn{3}{|c|}{ Difference Location Choice (Children-Others) } \\
\hline \multicolumn{3}{|c|}{ IV regressions } \\
\hline Public Housing(75) & \multicolumn{1}{|c|}{$0.473^{*}$} & \multicolumn{1}{|c|}{ European } \\
\hline x Arrival 75-82 & $(0.251)$ & $(0.143)$ \\
\hline First-stage Ficher & 9.8 & 10.6 \\
\hline \multicolumn{3}{|c|}{ 2. Constant Distribution Education and Age } \\
\hline Reference group: Non-Europeans with children in 1968 \\
\hline Public Housing(75) & $0.522^{* * *}$ & $0.358^{* * *}$ \\
\hline x Arrival 75-82 & $(0.193)$ & $(0.119)$ \\
\hline \multicolumn{3}{|c|}{ 3. Constant Distribution Education and Age } \\
\hline Reference group: Non-European with children in 1982 \\
\hline Public Housing(75) & $0.529^{* * *}$ & $0.353^{* * *}$ \\
\hline x Arrival 75-82 & $(0.191)$ & $(0.113)$ \\
\hline \multicolumn{3}{|c|}{ 4. Education $<$ High School } \\
\hline Public Housing(75) & $0.519^{* *}$ & $0.617 * * *$ \\
\hline x Arrival 75-82 & $(0.228)$ & $(0.224)$ \\
\hline \multicolumn{3}{|c|}{ 5. Education $\geq$ High School } \\
\hline Public Housing(75) & 0.189 & 0.233 \\
\hline x Arrival 75-82 & $(0.668)$ & $(0.725)$ \\
\hline Additional Controls & Yes & Yes \\
\hline Urban area FE & Yes & Yes \\
\hline N & 112 & 112 \\
\hline
\end{tabular}

Notes: In each column, the dependent variable is the difference in the log adjusted location probability between new immigrants with children and other new immigrants. This probability was estimated using a separate conditional logit model for each group and year. Each regression is weighted using the inverse of the standard deviation of the estimates of the dependant variable. Standard errors clustered at the urban area level are reported in parenthesis.

Statistically significant * at the .10 level; ** at the .05 level; *** at the .01 level. 
Table 8: Further Evidence on the Effect of Public Housing on the Location Choice of Immigrants

\begin{tabular}{|c|c|c|c|}
\hline \multicolumn{4}{|l|}{ 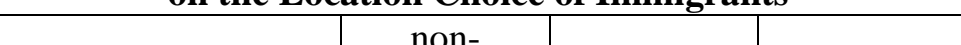 } \\
\hline 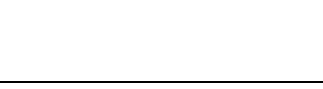 & $\begin{array}{c}\text { non- } \\
\text { European }\end{array}$ & European & $\mathrm{N}$ \\
\hline \multicolumn{4}{|c|}{ 1. Lead test } \\
\hline Public Housing 75 & 0.676 & 0.867 & 112 \\
\hline x Arrival 75-82 & $(0.631)$ & $(0.861)$ & \\
\hline Public Housing 90 & -0.159 & -0.867 & \\
\hline $\mathrm{x}$ Arrival 75-82 & $(0.462)$ & $(0.874)$ & \\
\hline \multicolumn{4}{|c|}{ 2. Excluding 10 Largest Cities from the Sample } \\
\hline Public Housing(75) & $0.633 * *$ & $0.390 * * *$ & 92 \\
\hline x Arrival 75-82 & $(0.273)$ & $(0.133)$ & \\
\hline \multicolumn{4}{|c|}{ 3. Un-weighted regressions } \\
\hline Public Housing(75) & $0.655^{* *}$ & $0.429 * * *$ & 112 \\
\hline x Arrival 75-82 & $(0.262)$ & $(0.154)$ & \\
\hline \multicolumn{4}{|c|}{ 4. Feasible GLS estimates } \\
\hline Public Housing(75) & $0.577 * * *$ & $0.568 * * *$ & 112 \\
\hline $\mathrm{x}$ Arrival 75-82 & $(0.029)$ & $(0.056)$ & \\
\hline \multicolumn{4}{|c|}{ 5. Household with an old child } \\
\hline Public Housing(75) & $0.528 *$ & $0.987 * *$ & 112 \\
\hline $\mathrm{x}$ Arrival 75-82 & $(0.276)$ & $(0.464)$ & \\
\hline \multicolumn{4}{|c|}{ 6. Only couples without children in the control group } \\
\hline Public Housing(75) & 0.444 & $0.889 *$ & 112 \\
\hline $\mathrm{x}$ Arrival 75-82 & $(0.339)$ & $(0.484)$ & \\
\hline \multicolumn{4}{|c|}{ 7. Only singles in the control group } \\
\hline Public Housing $(75)$ & $0.772 * *$ & $0.957 * *$ & 112 \\
\hline $\mathrm{x}$ Arrival 75-82 & $(0.313)$ & $(0.426)$ & \\
\hline \multicolumn{4}{|c|}{ 8. Effect on $1990 \& 1999$} \\
\hline Public Housing(75) & $0.569 * *$ & $0.371 * * *$ & 224 \\
\hline $\mathrm{x}$ Arrival 75-82 & $(0.267)$ & $(0.098)$ & \\
\hline Public Housing $(82)$ & $0.201 *$ & $0.451 * * *$ & \\
\hline x Arrival 82-90 & $(0.118)$ & $(0.124)$ & \\
\hline Public Housing(90) & 0.126 & $0.267 *$ & \\
\hline x Arrival 90-99 & $(0.096)$ & $(0.151)$ & \\
\hline Additional Controls & Yes & Yes & \\
\hline Urban area FE & Yes & Yes & \\
\hline
\end{tabular}

Notes: In each column, the dependent variable is the difference in the log adjusted location probability between new immigrants with children and other new immigrants. This probability was estimated using a separate conditional logit model for each group and year. Each regression is weighted using the inverse of the standard deviation of the estimates of the dependant variable. Standard errors clustered at the urban area level are reported in parenthesis.

Statistically significant $*$ at the .10 level; ** at the .05 level; *** at the .01 level. 
Table 9: Housing Quality and Employment Outcomes of New Immigrants and Public Housing Supply in 1982

\begin{tabular}{|c|c|c|}
\hline \multicolumn{3}{|c|}{ Dependent variable } \\
\hline \multicolumn{3}{|c|}{ A. Adjusted Share Living in a Moderately or Severely Overcrowded Home } \\
\hline & Non-European & European \\
\hline \multirow[t]{2}{*}{ 1. New Immigrants in 1982} & $-0.037 * *$ & $-0.029 *$ \\
\hline & $(0.017)$ & $(0.017)$ \\
\hline \multirow[t]{2}{*}{ 2. New Immigrant in 1968} & -0.010 & -0.014 \\
\hline & $(0.025)$ & $(0.020)$ \\
\hline \multirow[t]{2}{*}{ 3. Difference (1982-1968) } & -0.021 & -0.018 \\
\hline & $(0.024)$ & $(0.020)$ \\
\hline \multicolumn{3}{|c|}{ B. Adjusted Employment Rate } \\
\hline \multirow[t]{2}{*}{ 1. New Immigrants in 1982} & $-0.029 * *$ & 0.010 \\
\hline & $(0.013)$ & $(0.015)$ \\
\hline \multirow[t]{2}{*}{ 2. New Immigrant in 1968} & -0.001 & 0.008 \\
\hline & $(0.013)$ & $(0.004)$ \\
\hline \multirow[t]{2}{*}{ 3. Difference (1982 -1968) } & $-0.041 *$ & 0.008 \\
\hline & $(0.022)$ & $(0.013)$ \\
\hline $\mathrm{N}$ & 57 & 57 \\
\hline
\end{tabular}

Notes: Each entry represents the coefficient from a separate regression of the adjusted share living in overcrowded housing (panel A) or the adjusted employment rate in a given urban area (Panel B) on the public housing per household in 1982. The population of new immigrants include male new immigrants living in a household with children. Standard errors clustered at the urban area level are in parentheses.

Statistically significant $*$ at the .10 level; ** at the .05 level; *** at the .01 level. 